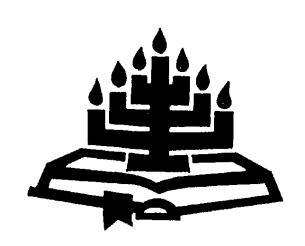

\title{
The role of the Bible in reformational philosophy: historical and systematic notes
}

\author{
R. Coletto \\ School of Philosophy \\ Potchefstroom Campus \\ North-West University \\ POTCHEFSTROOM \\ E-mail: renato.coletto@nwu.ac.za
}

\begin{abstract}
The role of the Bible in reformational philosophy: historical and systematic notes

In this article the role of the Bible in the elaboration of reformational philosophy, a neo-calvinist school founded in the 1930s by Dooyeweerd and Vollenhoven, is analysed. According to the author of this article, these two authors had somewhat different approaches to this problem, but their intentions were similar and the strategies they devised are compatible and even integrating each other. In practice, one might say that Vollenhoven favoured a more "textual" approach, while Dooyeweerd emphasised the importance of the biblical religious ground motive. The proposals of a more recent thinker in this movement, Jacob Klapwijk, are also explored and the promises and the "perils" of his approach are pointed out. The main purpose is to show that, in this philosophical tradition, the issue of the role of the Bible in philosophy has been tackled with discernment and devotion, stemming from a genuine commitment to the inscripturated Word.
\end{abstract}

\section{Opsomming}

Die rol van die Bybel in reformatoriese filosofie: historiese en sistematiese opmerkings

In hierdie artikel word die rol van die Bybel in die uitbou van die reformatoriese filosofie, 'n neo-calvinistiese beweging wat in die dertigerjare van die vorige eeu deur Dooyeweerd en Vollenhoven begin is, geanaliseer. Volgens die outeur van hierdie artikel, het hierdie twee outeurs verskillende benaderings tot 
hierdie probleem, maar hulle bedoelings was dieselfde en die strategieë wat hulle uitgedink het, was wel met mekaar versoenbaar en selfs met mekaar integreerbaar. 'n Mens kan sê dat Vollenhoven in die praktyk 'n meer "tekstuele" benadering gevolg het, terwyl Dooyeweerd die belangrikheid van die hooftemas in die bybelse religieuse grondmotief beklemtoon het. Die voorstelle van 'n meer resente denker in hierdie beweging, Jacob Klapwijk, word oorweeg en daar word op die beloftes en gevare van sy benadering gewys. Die hoofdoel is om aan te toon dat in hierdie filosofiese tradisie, die rol van die Bybel in filosofie met toewyding en ernstige ondersoek aangepak is - 'n houding wat uit 'n egte verbintenis aan die skrifgeworde Woord spruit.

\section{Introduction}

It is widely agreed that the Bible plays a crucial role in the shaping of a christian theology. The reformational school of philosophy has traditionally insisted that it plays a role also in the shaping of a christian philosophy. But how is the Bible supposed to function, to be "used" in philosophy? The latter should be regarded as the fundamental question of this article. Dooyeweerd argued that a philosophical approach to the Bible should not proceed by way of exegesis, i.e. by detailed and scientific analysis of the text. Some have raised their doubts, even their criticism, on the way some reformational philosophers have argued about this issue. At the same time, one must admit that there were several slightly different approaches and strategies deployed by different reformational circles.

This article tries to reconstruct, at least in part, some of these historical developments and to provide a few comments on the viability of the strategies that were deployed. The overall hypothesis is that the reformational school of philosophy produced a honest and necessary attempt at drawing from the Bible fundamental guidelines for a christian philosophy. By so doing, it has given a central place to the Bible in philosophical reflection.

By analysing especially the models proposed by Dooyeweerd and Vollenhoven it is argued that they are well elaborated and they should be regarded as compatible, even as integrating each other. It is also argued that a more recent model proposed by Klapwijk, though presenting several positive aspects, also presents some problematic sides requiring further elaboration and clarification. The purpose of this article is to show that in reformational circles the issue of the relationship of the Bible to philosophy has been tackled 
with discernment and devotion, stemming from a genuine commitment to the Word of God.

\section{Scripture and philosophy in dooyeweerdian circles}

\section{1 (How) can Scripture influence philosophy?}

Christian philosophy, according to Dooyeweerd, finds its basis in the whole Bible, not in specific verses or books. The way philosophy approaches the Bible is not through exegetical analysis. The latter would require a particular exegetical expertise (Dooyeweerd, 1980: 148) which philosophers don't have. Such exegetical approach would also make christian philosophy too dependent on theology (Dooyeweerd, 1959:66) and therefore unable to access the very source of its inspiration by itself. No, philosophy has a different and more appropriate method than exegesis to access the Bible. Or, if we prefer, there is a particular way in which the Bible influences philosophy - via the biblical religious ground motive. According to the Dutch philosopher, the central and integral religious motive of the Bible can be described by the formula "creation, fall and redemption through Christ Jesus in the communion of the Holy Spirit" (Dooyeweerd, 1966:14).

This is the central motive of the Bible, one could say its "concentration point" (as Dooyeweerd used to call the heart with respect to man). It is, in a sense, the summary of the Bible, and it is something philosophy can deal with. It is from this basis that Christian philosophy looks at created reality as its field of study. Of course one must also remember that creation itself is a form of revelation, and it is therefore essential for christian philosophy and scholarship.

Philosophy is, therefore, based on the Bible, but not in a simplistic way. Philosophy should not try to prove its conclusions by quoting biblical verses. It should rather be based on a broader perspective, a ground motive concentrating in itself the whole biblical revelation. Such a religious motive, says Dooyeweerd (1959:65), is "independent from every theological exegesis". 1 (I will briefly return on this issue towards the end of 2.2.)

One should take into account the possibility that Dooyeweerd shaped his particular approach also to avoid skirmishes on the exe-

1 All direct quotations from Dooyeweerd (1959) are translated from the French by the author (RC). 
getical ground. Many Dutch theologians of his time, in fact, were often rather suspicious of the new philosophy and usually reluctant to accept with sympathy the young and sophisticated ancilla. In Klapwijk's (1987:107) opinion, one of the main reasons why Dooyeweerd chose to direct philosophy to this religious motive (and not to the biblical text itself), was that he suffered the extenuating attacks of theologians, who criticised the new philosophy on exegetical grounds.

We need to pause here for a moment. Could Dooyeweerd's solution imply a dichotomy between the text of the Bible and its religious ground motive, which is regarded as supra-theoretical? After all, the religious ground motive is not identical to the Bible, although it is considered its summary, its heart, its power, et cetera. Several scholars expressed their perplexities, in this respect. We will return on this topic in 4 , to include other objections raised against the dooyeweerdian and vollenhovian 2 schools.

For the moment a positive trait of the dooyeweerdian model should be acknowledged. In Dooyeweerd's view christian philosophy is based on the biblical religious ground motive, just like any other type of scholarship is based on some religious ground motive. This means that christian scholarship (although different in its "direction") is structurally the same as any other type of scholarship. And this idea allows the christian scholar to feel fully entitled to present his contributions in the public arena of scholarship.

\subsection{The role of worldviews}

Initially Dooyeweerd accepted the idea that between a religious ground motive and philosophy there is another "filter" or bridge, namely a worldview. According to Wolters (1989:22-23) in the 1930s Dooyeweerd saw no particular problems in admitting the presence and the usefulness of a calvinist worldview between philosophy and the biblical ground motive. Yet already from 1935 things started to change. Dooyeweerd developed a new position. ${ }^{3}$

2 The term is an abbreviation of "vollenhoven-ian", which I would like to avoid, for stylistic reasons.

3 For the initial position of Dooyeweerd, Wolters (1989:25, fn. 9) mentions: DOOYEWEERD, H. 1924-1925. In den strijd om een Christelijke Staatkunde. Proeve van een fundeering der Calvinistische levens-en wereldbeschouwing in hare wetsidee. Antirevolutionaire staatkunde, (1):7-25. (See also subsequent issues until 1927.) 
Philosophy, in his view, should not simply result from the elaboration of something particular or local (like a worldview) otherwise it would loose its claims to universal validity. It is not by chance that philosophy is considered the elaboration of a worldview especially in the romantic tradition. Following Taylor, Klapwijk (1989:51) speaks of an "expressivist" view: every community develops its own worldview, even its own philosophy and science which are in the end "expressions" of its own spirit. In this way the claim to universality is abandoned in favour of a fascination with the particular and the local. Dooyeweerd was determined to avoid this solution.

From the middle 1930s, according to Wolters, Dooyeweerd started to develop a new position, namely that a worldview is not the basis for philosophy (and scholarship), but rather "flanks" philosophy. Worldview and philosophy are like two different trees growing on the same soil (i.e. on religion). Philosophy therefore is not like a branch growing on the trunk of a worldview. A worldview flanks philosophy, according to a model that Wolters (1989:22-23) is even tempted to consider as related to the lutheran worldview, placing "grace alongside nature".

Yet, as Wolters admits, in Dooyeweerd's case, the difference is that both philosophy and worldview are based on religion. This model can rather be regarded, then, as something original. Furthermore, Klapwijk rightly objects to Wolter's opinion that the relationship between philosophy and worldview might parallel the relationship between nature and grace in the lutheran tradition (Klapwijk, 1989:48$50)$.

Klapwijk agrees with Dooyeweerd that when a worldview functions as the basis of philosophy, it historicises the latter. And relativism was exactly what Dooyeweerd tried to avoid. In his view philosophy has the task of providing an account of reality that can have universal validity. Its claim should transcend both local community and historical epoch, to propose itself to everybody.

This is, by the way, the reason why Dooyeweerd in his later years, preferred to speak of a christian (and not of a calvinist) philosophy (Dooyeweerd, 1984, 1:524). He wanted to produce a philosophy based on the groundmotive of the Word of God, not on the relative basis of the worldview of a reformed community in the Netherlands, in the first decades of the twentieth century. For the same reason he (Dooyeweerd, 1966:15) also insisted that such philosophy is not based on the "gereformeerde beginselen" (reformed principles) 
which are theological and theoretical in character, and are confessional expressions of a particular christian community.

Should then a calvinist worldview play no role at all in reformational philosophy? We will later come back to this question (in 6) and we will examine Klapwijk's answer. Concerning my opinion, I would say that although in Dooyeweerd's model philosophy is not based on or determined by a worldview, this does not eliminate all possibilities of interaction. The possibilities lie in the fact that a worldview still "flanks" philosophy.

\section{Bible and philosophy in vollenhovian circles}

Vollenhoven too is convinced that the Bible "may not be taken as a handbook for philosophical (...) knowledge" (Vollenhoven, 1941:4). Though excluding a "proof-text" approach, however, scholars in the vollenhovian tradition promote a more direct interaction between Scripture and philosophy. In this model christian philosophy finds its starting point directly in the written revelation. "Of course, for them too the Word of God is a driving and inspiring power", says Klapwijk, "yet they believe that through a direct appeal to Holy Writ, the light of the biblical revelation must still be allowed to shine in all its fullness in philosophical discourse" (Klapwijk, 1987:107-108).

It is not usual, in this circle, to hear of a religious ground motive that summarises the Bible and makes it understandable for science. Vollenhoven wrote a few sentences which summarise quite well the position of this school.

If you believe God's Word, and trust that Word, you obtain a philosophy the basis of which is formed by that non philosophical, non scientific belief in Holy Scripture and in God. (Vollenhoven, 1953:8; 1992:103.)

Klapwijk reveals that, in a private conversation, Vollenhoven himself confided to him that in his opinion it was impossible "to summarize the richness of the biblical message in 'such a formula' (he meant Dooyeweerd's religious ground motive)"4 (Klapwijk, 1987:107). Be-

4 Yet, Vollenhoven (1935) did provide his own summary of the biblical text and even called it "groundmotive". In the first chapter of his, The relationship of the Bible to learning, Runner too seems to be quite positive towards Dooyeweerd's idea of religious ground motives. Van der Walt often argued about the strategic importance of worldviews. This shows that all schematic attempts at defining the approach of a plurality of authors have their limits. My impression is that, although the vollenhovian emphasis on direct access to the biblical text is real, 
ing educated in theology as well, Vollenhoven seemed to feel more at ease than Dooyeweerd with biblical quotations.

Vollenhoven's interaction with the Bible, however, was never simplistic. In his main systematic work (Vollenhoven, 2005; original 1930) his references to the Bible remain discrete and pervasive at the same time. Christian philosophy, according to Vollenhoven (2005:14), should be "scriptural" and "in line with Scripture", certainly not biblicistic in its approach. He shows that the Bible supplies answers to questions which are fundamental for philosophy in general. On the basis of those guidelines a Christian philosopher is enabled to find orientation and to avoid solutions which would clash with his religious commitment (cf. Vollenhoven, 2005:15-18).

Some vollenhovian authors (e.g. Taljaard), however, are even more "generous" in their direct appeal to the Bible in the context of philosophical argumentation. Runner's approach is a good example. When discussing the idea of sphere sovereignty, Runner (1970) does not only refer to Althusius, Kuyper or others who elaborated this idea. He tries to show, in addition, that the idea itself plunges its roots in the Bible. We find in Marshall (1991:7-10), a dooyeweerdian, the view that sphere sovereignty is derived, basically, from the biblical worldview. This, however, seems not to be enough for Runner. He prefers to quote specific verses as well.

He starts from broad biblical themes: the human heart (Runner, 1970:144), then the idea of "office" (Runner, 1970:145) the central rule of Christ and the church-institute (Runner, 1970:147). When he is ready to discuss the limits of the authority accorded to every sphere, the Bible is quoted more in detail.

Thus, for instance, the husband's authority is not derived from the state, of which he is a citizen or subject, but from Christ himself. (Cf. Eph. 5:23 ff. with 1 Cor. 11:3; Runner, 1970:148.)

And he continues, a few lines below:

With this construction [sphere sovereignty] a great mass of biblical data falls into place, not only the limited authority of the king in the Old Testament theocracy (II Cron. 26) but also such apostolic instructions as are given in Ephesians 5:15-6:9. The

eventual (pre-scientific) intermediaries are not totally excluded by all authors. Such intermediaries don't become monopolistic "mediators" and in general the emphasis remains on the biblical text. 
divine delegation of office in the life of the state is clear from many places in Scripture, especially from what Jesus said to Pilate. And the interesting passage in Psalm 82 relating to the judges in Israel ('I said, ye are gods ... nevertheless ye shall die like men') simply cannot be uderstood apart from a distinction between the office and the man who holds the office. (Runner, 1970:148-149.)

Runner admits that there is no mention of the term sphere sovereignty in the Bible. So the "scriptural proof" is in a sense "indirect". $\mathrm{He}$ is not inclined to biblicism. Yet, the whole Bible supports the idea of sphere sovereignty, in his view, just as it supports the idea of holy trinity, which is nevertheless never mentioned as such in the Bible.

I am sometimes asked what proof-texts there are for sphere sovereignty (...). No; there are not, if you want a single verse. But at least the theologians among us know that a similar state of affairs prevails with respect to such a fundamental doctrine as that of the Trinity (...). In like manner I would say of sphere sovereignty that its biblical proof is the integral meaning of scriptural revelation; without sphere sovereignty the Scriptures simply cannot be understood. (Runner, 1970:151.)

The purpose of the above quotations is to show Runner's sensitivity to exegetical problems. Spykman (1985:48-69) shows the same sensitivity towards biblical hermeneutics. The model proposed by this school is fascinating and challenging, provided, I would say, a few preliminary issues be addressed. There are, in fact, a few questions that might be raised by this type of approach.

- Is philosophy (or any other science) equipped for an exegesis of the Bible? How will it understand the text and avoid arbitrary or incorrect interpretations?

- Does the Bible speak to philosophy (and to the other sciences) as well?

- And if it could, we have Klapwijk's question:

Let us suppose for a moment that Christian theology may be described as theoretical reflection on the biblical revelation (...) where then remains the difference between such a scriptural philosophy and Christian theology? (Klapwijk, 1987:106.)

Unfortunately, a truly systematic answer to these questions has not been provided by the supporters of this school. Nevertheless, as far 
as I am concerned, I have argued that the project is viable (Coletto, 2002:35-37). 5 In addition, it may constitute a desirable integration of the dooyeweerdian approach. In fact, one may argue that the vollenhovian approach insists especially on the importance of specific biblical texts, while the dooyeweerdian model insists on broader, more encompassing themes (e.g. the distinction between Creator and creature). From my point of view, an integration of the two approaches is possible and fruitful.

For example, Hart (1984) has fruitfully integrated the two approaches by showing that the rather poignant elaborations of his ontology are based on both specific biblical texts and broader themes. It is in the appendix to his ontological work (in which he makes more explicit the biblical basis of his work), that Hart (1984) quotes especially biblical verses. The foundation of his admirable ontology in the reformed tradition is in the written Word of God.

Yet the reformational approach has sometimes raised objections and perplexities as well. This is the topic of the next section.

\section{Excursus: some objections to the reformational approach}

Starting from the 1960s some philosophers from both dooyeweerdian and vollenhovian circles have been accused of holding an unorthodox doctrine of the Scriptures. ${ }^{6}$ For example, vantilian ${ }^{7}$ authors like Frame and Coppes (1972:32-40) asked what exactly a "religious ground motive" was. The dooyeweerdian idea of a dunamis (power) of the Word of God was rather suspect to others (e.g. Sheperd, 1969). What kind of "power" did Dooyeweerd have in mind? Was it a power apart from the biblical text, above it, or in the text itself? Why

5 Though not proposed in direct relation to the vollenhovian project or model, see also my comments in Coletto (2009:303-307).

6 For a good overview of the debates, meetings and publications surrounding this discussion, see Downs (1974).

$7 \quad$ The adjective "vantilian" refers to scholars building on the work of the renowned reformed theologian and apologist Cornelius Van Til (1895-1987). A major figure in twentieth-century's Dutch-American calvinist circles, Van Til interacted fruitfully with reformed philosophers like Dooyeweerd, the South African H.G. Stoker and others. 
was the biblical ground motive regarded as supratemporal?8 ${ }^{8}$ The idea of a "power" possibly separated from the text necessarily caused some perplexity among those scholars. In fact, it is typical of certain spiritualist traditions to create an excessive distance between the Word and the Spirit.

What was the response from the reformational circles? It was replied that those perplexities are not immune from a rather rationalist attitude. The Bible itself, says Schrotenboer (1969), teaches that the Word of God is a power (1 Tess. 2:13; Heb. 4:12). Such power cannot be reduced to a certain amount of propositions to be apprehended logically. ${ }^{9}$ The Bible cannot be qualified by the logical modal aspect. Its central religious motive is supra-theoretical, as it addresses human hearts (Isa. 6:10; Acts 16:14) not only (or especially) human brains (Schrotenboer, 1969). Indeed Dooyeweerd (e.g. 1984, $1: 88)$ placed abundant emphasis on the idea that the human heart is the medium through which the ground motive gives direction to all concrete cultural expressions.

In this case it is interesting to observe that even the dooyeweerdian defence of its views on the Bible was based on exegetical grounds (and not simply derived from a "ground motive").10 Probably the defence did not convince everyone. Yet, it constituted, in my opinion, a sound attempt at dealing with these problems from a honest kuyperian point of view.

In this context one should mention the equally vantilian objection that reformational philosophy was not sufficiently "exegetical". For example Frame and Coppes (1972:37) observed that Dooyeweerd's view of the six days of Genesis 1 "does not arise through study of

8 Some authors (e.g, Taljaard, 1976) have suspected a tendency, in Dooyeweerd's thought, to create a "duality" between temporal and supratemporal, in the context of a monarchian pattern of thought. The alleged problem would be related to several areas of reflection. For a discussion of his supposedly "monarchian" inclinations in anthropology, see for example Fernhout (1979).

9 In this respect one should take into account the long tradition according to which Scripture and faith are said to be "logical". The idea can be found already in Augustinus (1995, De doctrina christiana 2.39.59).

10 Here I have the opportunity to observe again (see fn. 4) that one should avoid too rigid assessments of the approach of a variety of authors over a long period of time. For example, the reader of Dooyeweerd's (1979) Roots of western culture, will have difficulties accepting the conclusion that the dooyeweerdian approach is reluctant to deal with "exegesis" or with concrete biblical verses. 
the Hebrew text". This type of objection has been answered by Berkouwer (1971:200 ff.). Frame (1976:27) summarises Berkouwer's reply in a question: "[l]f Scripture has such primacy for Van Til, why is his method not more 'exegetical?"' Indeed, the famous apologist of Westminster Seminary is more "systematic" than exegetical in his approach. Frame (1976:27) admits that on this point "Berkouwer has chastened Van Til", and the latter "has admitted guilt" (cf. Van Til, 1971:203 ff.).

Nevertheless, Frame replies that "we must rethink [...] what 'exegesis' is", and asks the following:

[l]s Van Til not doing 'exegesis' when he translates the biblical concepts into philosophical language? [...] When all is said and done it will be seen that Van Til's work is indeed exegetical. (Frame, 1976:28.)

Without evaluating the merit of Frame's argument, I would only like to suggest that if it is valid for Van Til, it should be applied to Dooyeweerd and his school as well. Then the objection that their philosophy is not sufficiently "exegetical" should be reconsidered.

It is also possible to remember, in this context, that the reformational school met several objections concerning the nature of the Word of God. For example, several reviewers of Spykman's (1991) Reformational theology have noticed the risk that in Spykman's account the word may become a tertium quid between Creator and creature (e.g. Gaffin, 1994:387). According to Spykman (1991:79) the word "is subservient to God Himself. At the same time it transcends the creation". Williams summarises Spykman's position by arguing that the three forms of the Word of God (creation, Scripture and Christ) are represented as "neither divine nor creaturly" (Williams, 1992:31). Then he asks: If such a solution may pose no problem to the creational and scriptural words, what about the nature of Christ?

One might try to solve the difficulty by saying (cf. Hart, 1984:341342 ) that the Word of God is both creaturly and divine. However, if this may pose no problem for the incarnate and the inscripturated Word, what about the Word for creation? On this point, several clarifications would be necessary and appreciated. (I notice that in his most recent book Van der Walt (2010:196-198) has aptly summarised this debate and has again called attention to both its historical roots and its implications.) 
One final difficulty concerned the scope of biblical authority. While Olthuis (1976:15) argued that the Bible has a soteriological scope, Duvenage objects (rightly in my opinion) that a

... redemptive historical or soteriological narrowing of the scope of the inscripturated Word to our mind, goes against the line of thought of the Reformational tradition, as disseminated especially by Calvin, Kuyper and Bavinck, but what is more important, it is also against the testimony of the Scriptures (Duvenage 1985:10).

This difficulty, however, is by no means a necessary outcome of adopting reformational philosophy. It is often the result, rather, of particular denominational views. For example, Olthuis' view that the Bible has a soteriological focus (not a broader focus, as Duvenage would like to say) parallels the pronouncements of the acts of a synod of the Christian Reformed Church (1972:507).

In all the above cases, however, it seems excessive to speak of unorthodox positions and it seems quite possible to adjust the difficulties. Probably a closer cooperation with the theologians would help elaborating more adequate formulations. Already in the 1970s Zylstra (1975:32) pointed out that the reformational movement did not have sufficient theological expertise to elucidate and clarify better its proposals in this particular context.

Whatever the case might be, it should also be acknowledged that, in its reflection on the Bible, reformational philosophy has not only raised stubborn problems. It has also contributed to new critical insights. For example, dualistic patterns of thinking were pointed out (e.g. the duality between special and general revelation), rationalistic tendencies were detected (see above) and reductionist inclinations were denounced (e.g. restricting the Word of God mainly to the Bible).

Let us now move to a more recent reformational philosopher who has dealt quite extensively with the topic of the use of the Bible in philosophy.

\section{Jacob Klapwijk on Scripture and philosophy}

\subsection{The mediating role of worldviews}

Klapwijk has new proposals to offer in the discussion concerning the relationship between Scripture and philosophy. In his view the missing link between the Bible and philosophy is exactly "the so- 
called life and world view" [sic] (Klapwijk, 1987:108). By acknowledging this fact, suggests Klapwijk, one will understand the relationship between Bible and scholarship much better. For example, the reason why the philosophies of Dooyeweerd and Vollenhoven are so similar, in his opinion, is to be found in the use of the same (reformed) worldview.

Thus Vollenhoven could speak of 'Scriptural philosophy' and Dooyeweerd could mention a 'central biblical ground motive' as long as (...) in doing so they understood 'scriptural' and 'biblical' within the historical tradition of the 'calvinist' worldview. The context provided by this worldview (...) can be traced in retrospect as the binding element. (Klapwijk, 1987:108.)

Klapwijk (1987:109) is aware that his view "is fraught with not insignificant systematic considerations". He (Klapwijk, 1987:109) is aware that "perhaps some will experience this turn to matters of worldview as a historicizing, yes a relativizing of our own position". Yet the latter is not Klapwijk's intention. "My position does not imply a kind of Christian relativism", he assures us (Klapwijk, 1987:109). His purpose is rather to show two things. Firstly, that all philosophy, not only reformed philosophy, has worldview roots. Secondly, that reformed philosophy is not simply founded in Scripture nor driven by an exclusively religious motive, but "has concrete historical roots" in a certain worldview (Klapwijk, 1987:109).

Klapwijk wants to show, in practice, that what Dooyeweerd called "religious ground motives" in the western philosophical tradition, were actually worldviews. In fact "according to the doctrine of the religious antithesis", says Klapwijk (1987:109), "one can speak at most of two religious motives" (i.e. biblical or unbiblical). According to Klapwijk (1987:109), Dooyeweerd had rather in mind "four religiously oriented worldviews" and it is not difficult to see that he borrowed the idea from the Stone Lectures of Kuyper "who speaks there [...] more specifically, of paganism, romanism, modernism and calvinism which he calls all-embracing worldview positions".

It was only because Dooyeweerd was actually speaking of worldviews that he could show how religion, via the so-called "cosmonomic idea", can influence philosophy.

Yet such an endeavor is impossible if indeed religion, in the Dooyeweerdian sense of ultimate commitment, is at stake, because religion transcends all scholarly exposition. (Klapwijk, 1987:109.) 
Dooyeweerd could accomplish his task because he demonstrated not how religion, but how worldviews do enter philosophy (Klapwijk, 1987:109).

This view has, for Klapwijk, two immediate consequences. Firstly, the difference between the models of Dooyeweerd and Vollenhoven is relativised. The one spoke about the "inspiring power" of religious motives and the other appealed to the "witness of Holy Scripture". However, the two should be seen as complementary, "for in living with God's Word the Christian receives both instruction and inspiration" (Klapwijk, 1987:110).

Secondly, Klapwijk (1987:106 - see 3 above) comes back to a previous observation that "Vollenhoven's philosophy entails a serious difficulty, namely the question of its relation to theology". If philosophy too is a reflection on the Bible, how can it be distinguished from theology? Now he can say that, for those who accept his suggestions, "there is no need to convert such a 'scriptural' philosophy itself into theology" (Klapwijk, 1987:110). Klapwijk (1987:106) means, if I understand him well, that the insertion of a worldview between philosophy and Scripture allows philosophy not to be directly "a theoretical reflection on the biblical revelation". Philosophy would rather be a reflection on the biblical worldview, thus avoiding to be confused with theology.

However, Klapwijk has to face the possible objections of those who may consider his operation a relativising of christian philosophy. Klapwijk (1987:110) declares that he has no sympathy for a "German romantic and historicist notion of Weltanschauungsphilosophie" as promoted, for example by Dilthey. He is fully aware of the dangers implied in this "expressivist" vision of philosophy (the latter as mere "expression" of a particular worldview). Such a philosophy would forfeit its claim to universality (as already discussed in 2.2).

Klapwijk, however, does not provide more explanations in this article to those who fear his relativism. He (Klapwijk, 1987:110, fn. 17) just refers to his contribution of 1989 for a clarification of his views. The problem is that in his contribution of 1989 Klapwijk never answers this question.11 Admittedly, in the long run some additional infor-

11 In that article Klapwijk (1989:54) does point out that it is necessary to safeguard both the universality of philosophy (Dooyeweerd's concern) and the impact of worldviews (Kuyper's concern, in Klapwijk's view). In order to do so, he declares that a transcendental and hermeneutical idea of philosophy is needed. Nevertheless, the article is concluded by the following words: "I shall break off 
mation was offered (cf. Klapwijk, 1991:256 ff.; 2008:195 ff.). Given the importance of the issue, one would, however, have hoped for more elaborate and systematic explanations, more directly linked to the initial discussion. I am referring, for example, to the initial challenge of combining "worldview commitments and well-founded claims to universality", or to the idea that worldviews mediate between religion and philosophy.

In the following two sections critical remarks will be concentrated on two areas, namely the relationship between philosophy, Scripture and pre-scientific frameworks (5.2) and the theme of mediation (5.3).

\subsection{Critical remarks: philosophy, Scripture and pre-scientific frameworks}

Klapwijk argues that both Dooyeweerd and Vollenhoven were "inspired" (without being aware of it?) by a calvinist worldview. How does he prove his point? According to Klapwijk (1987:108) the presence of a shared worldview explains why their philosophies are sufficiently similar. But was not their basic religious motive also the same? Would this not explain the agreement between their philosophies as well as the disagreement with their catholic, lutheran or neo-orthodox colleagues, all theorising on the basis of another religious motive?

Klapwijk (1987:109) may object that religious motives "transcend all scholarly exposition", therefore they cannot have a direct impact on philosophy. Yet Dooyeweerd's efforts to demonstrate the link between religion and philosophy should not be dismissed in such a haste. They deserve a bit more consideration. I am not only thinking of the transcendental critique that tried to prove the existence of this inner contact between religion and theoretical thought. I think also of the lengthy and detailed discussions provided by Dooyeweerd to show how a few different religious ground motives directed, historically, the concrete developments of western philosophy.

One should also mention Klapwijk's concern about philosophy being confused with theology. The solution offered by Klapwijk is that theology should be regarded as a (theoretical) reflection on Scripture, while philosophy as a reflection on worldviews. Klapwijk's solution,

my contribution at this point. It would require a separate article (...) to explain how such an idea can allow both worldview commitments and well-founded claims to universality." 
however, may harbour its problems. As a matter of fact, philosophy (in order to be distinguished from theology), is somehow "separated" from Scripture. In this way a scriptural philosophy is indeed distinguished from theology, but one has to admit that the adjective "scriptural" is quite weakened in the process.

Finally, there are a couple of questions which emerged from reformational circles and should not be ignored. The first one is posed by Groenewoud (1987:167). Does Klapwijk's model explain the relationship between Scripture and science better, or does it simply "shift the discussion to the question how a worldview may enter into philosophical discourse"? The second question is posed by Geertsema (1987:160). Is a transcendental critique of theoretical thought, in the dooyeweerdian sense, still possible for Klapwijk? The possibility of such a critique is granted by the recognition of an inner point of contact between religion and theoretical thought. In Klapwijk's model, says Geertsema, this direct contact may not be possible anymore. Both questions, I would say, insist on problems that are related to the theme of mediation, which is discussed in the next section.

\subsection{Critical remarks: the problem of mediators}

It should be admitted that mediators often constitute an element of obstruction (rather than conjunction) in the relationship between the two factors they try to link (in our case Scripture and philosophy). Once a worldview becomes the mediator between philosophy and Scripture, for example, the risk is that philosophers might refrain from dealing with the Bible at all, and might erect their reflections on a christian worldview.

In Klapwijk's model, the mediators are even multiplied. Geertsema (1987:146) summarises the idea in a few words: in Klapwijk's philosophy of scholarship "the contact between religion and science takes place via a number of intermediate levels". He further explains that "Klapwijk identifies these intermediate levels as one's religious commitment, personal conception of life, worldview and the practical ethos of one's community". All this concerns the pre-scientific level of reflection. To this, one should also add the mediation of philosophy with respect to the special sciences, on the scientific level. This "chain" of intermediaries has quite a number of rings.

I resort to the chain-metaphor, because Klapwijk gives the impression that, in his model, the intermediaries are conceived as standing in a sequence. The impression is that each "ring" connects the pre- 
vious one to the next one, like in a chain. In such a project one may still say, for example, that a worldview is connected with a special science via the mediation of philosophy. But for that special science, is there still access to the worldview level apart from the mediation of philosophy?

The answer does not necessarily have to be negative. In fact, Klapwijk's most recent views seem to allow for more mutual interaction between the different epistemic "players". I must limit myself to one example: when stating his "four hermeneutic rules" (Klapwijk, 2008: 205), though the usual idea of a sequence remains implicit, Klapwijk also says that "every worldview or philosophy elicits scientific investigations aimed at the confirmation of the position that is taken". Here worldviews seem to be capable of generating special scientific investigation without the monopolistic mediation of philosophy.

Perhaps the epistemic players mentioned by Klapwijk instead of being conceived as the successive rings of a chain or as concentric circles (cf. Klapwijk, 2008:200), could be regarded as elements operating in a "network". The change of metaphor would then make room for multiple influences and reference points in a dynamic interaction of scientific and pre-scientific factors. It is possible that this model may not be too far from Klapwijk's intentions, in his most recent publications.

Before moving to a conclusion, I would like to point out that although I have provided several critical remarks they are not meant to dismiss Klapwijk's contribution. They are rather offered in view of an improvement of this approach, which I believe, contains important and positive elements. For example, the idea that there is an influence of worldviews on philosophy and that such influence should be acknowledged and regulated rather than denied, seems to me quite important.

\section{Conclusion}

What emerges from this brief survey, I believe, is that in the reformational tradition there has been an honest and intense effort to deal in a discerning way with the issue of the role of the Bible in the philosophical reflection. There has been a determination to include the biblical text in the process of elaboration of philosophical perspectives. Some might insist that the results were not always the best possible. Others may point out shortcomings and insufficiencies. However, one should also appreciate the attempt at producing philosophy in die Skriflig, the intention to allow the light of the 
biblical Word to keep shining on the tortuous path of philosophy. As one considers the oppositions that this project obviously encountered in an increasingly secularised world, this effort should inspire a sense of gratitude.

\section{List of references}

AUGUSTINUS, A. 1995. De doctrina christiana. T. 2.39. Oxford: Clarendon.

BERKOUWER, G.C. 1971. The authority of Scripture: a responsible confession. (In Gehaan, E.R., ed. Jerusalem and Athens. Nutley: Presbyterian \& Reformed Publication Company. p. 197-202.)

CHRISTIAN REFORMED CHURCH. 1972. Acts of synod. Grand Rapids: Christian Reformed Church.

COLETTO, R. 2002. Models of scholarship in the reformed tradition. Potchefstroom: PU for CHE. (M.A. thesis.)

COLETTO, R. 2009. Strategies towards a reformation of the theology-based approach to Christian scholarship. In die Skriflig, 43(2):291-313.

DOOYEWEERD, H. 1959. Cinq conferences. La revue reformee, 10(3):3-76.

DOOYEWEERD, H. 1966. Het oecumenisch-reformatorisch grondmotief van de wijsbegeerte der wetsidee en de grondslag van de vrije universiteit. Philosophia reformata, 31(1-2):3-15.

DOOYEWEERD, H. 1979. Roots of western culture: pagan, secular and christian options. Toronto: Wedge.

DOOYEWEERD, H. 1980. In the twilight of western thought. Nutley: Craig.

DOOYEWEERD, H. 1984. A new critique of theoretical thought. Jordan Station: Paideia.

DOWNS. H.L. 1974. The distinction between power-word and text-word in recent reformed thought: the view of Scripture set forth by some representatives of the philosophy of the law-idea. Nutley: Presbyterian \& Reformed Publishing Company.

DUVENAGE, B. 1985. Christian scholarship as Word-bound scholarship. Potchefstroom: PU for CHE. (Potchefstroom Studies in Christian Scholarship.)

FERNHOUT, H. 1979. Man faith and religion in Bavinck, Kuyper and Dooyeweerd. Part 3. Tydskrif vir christelike wetenskap, 15(3 \& 4):119-140.

FRAME, J.M. 1976. Van Til: the theologian. Chattanooga: Pilgrim.

FRAME, J.M. \& COPPES, L. 1972. The Amsterdam philosophy: a preliminary critique. Phillipsburg: Presbyterian \& Reformed Publication Company.

GAFFIN, R.B. 1994. A new paradigm in theology? The Westminster theological journal, 56(2):379-390.

GEERTSEMA, H.G. 1987. Christian philosophy: transformation or inner reformation? Philosophia reformata, 52(2):139-165.

GROENEWOUD, G. 1987. Scripture, philosophy and worldview: a comparison between Herman Dooyeweerd and Jacob Klapwijk. Philosophia reformata, 52(2):166-181.

HART, H. 1984. Understanding our world: an integral ontology. Lanham: University Press of America.

KLAPWIJK, J. 1987. Reformational philosophy on the boundary between the past and the future. Philosophia reformata, 52(2):101-134. 
KLAPWIJK, J. 1989. On worldview and philosophy: a response to Wolters and Olthuis. (In Marshall, P.A., Griffioen, S. \& Mouw, R.J., eds. Stained glass: worldviews and social science. Lanham: University Press of America. p. 41-55.)

KLAPWIJK, J. 1991. Epilogue. (In Klapwijk, J., Griffioen, S. \& Groenewoud, G., eds. Bringing into captivity every thought: capita selecta in the history of christian evaluation of non-christian philosophy. Lanham: University Press of America. p. 241-266.)

KLAPWIJK, J. 2008. Purpose in the living world? Creation and emergent evolution. Cambridge: Cambridge University Press.

MARSHALL, P. 1991. A calvinist political theory. Potchefstroom: PU for CHE. (Institute for Reformational Studies.)

OLTHUIS, J.H. 1976. The Word of God and biblical authority. Potchefstroom: $\mathrm{PU}$ for $\mathrm{CHE}$. (Instituut vir die bevordering van Calvinisme.)

RUNNER, H.E. 1970. The relation of the Bible to learning. Toronto: Wedge.

SCHROTENBOER, P.G. 1969. A reply to professor Sheperd. International reformed bulletin, 12(38):21-26.

SHEPERD, N. 1969. God's Word of power. International reformed bulletin, 12(38):17-20.

SPYKMAN, G.J. 1985. Spectacles: biblical perspectives on christian scholarship. Potchefstroom: PU for CHE.

SPYKMAN, G.J. 1991. Reformational theology: a new paradigm for doing dogmatics. Grand Rapids: Eerdmans.

TALJAARD, J.A.L. 1976. Polished lenses. Potchefstroom: Pro Rege.

VAN DER WALT, B.J. 2010. At home in God's world: a transforming paradigm for being human and for social involvement. Potchefstroom: Institute for Contemporary Christianity in Africa.

VAN TIL, C. 1971. Response by C. van Til. (In Gehaan, E.R., ed. Jerusalem and Athens. Nutley: Presbyterian \& Reformed Publication Company. p. 202-203.)

VOLLENHOVEN, D.H. Th. 1935. Die Grundlagen der calvinistischen oder schriftgemaszen Philosophie. Theologische Blatter, 24:46-56.

VOLLENHOVEN, D.H. Th. 1941. Historia philosophiae. Amsterdam: Vrije Universiteit. (Stenciled syllabus.)

VOLLENHOVEN, D.H. Th. 1953. Schriftgebruik en wijsbegeerte. Mededeelingen van de Vereeniging voor Calvinistische Wijsbegeerte: 6-9, Sept.

VOLLENHOVEN, D.H. Th. 1992. Schriftgebruik en wijsbegeerte. (In Tol, A. \& Bril, K.A., eds. Vollenhoven als wijsgeer: inleidingen en teksten. Amsterdam: Buijten \& Schipperhijn. p. 97-106.)

VOLLENHOVEN, D.H. Th. 2005. Introduction to philosophy. Ed. by J.H. Kok \& A. Tol. Sioux Center: Dordt College Press.

WILLIAMS, M. 1992. Review of G.J. Spykman: Reformational theology: a new paradigm for doing dogmatics. Pro rege, 20(4):30-32.

WOLTERS, A.M. 1989. On the idea of worldview and its relation to philosophy. (In Marshall, P.A., Griffioen, S. \& Mouw, R.J., eds. Stained glass: worldviews and social science. Lanham: University Press of America. p. 14-25.)

ZYLSTRA, B. 1975. Introduction. (In Kalsbeek, L. Contours of a christian philosophy: an introduction to Herman Dooyeweerd's thought. Amsterdam: Buijten \& Schipperheijn. p. 14-33.) 


\section{Key concepts:}

belief and philosophy, relationship between philosophising, role of the Bible in scriptural philosophy, Dooyeweerd's view of scriptural philosophy, Klapwijk's view of scriptural philosophy, Vollenhoven's view of worldview, Scripture and philosophy

\section{Kernbegrippe:}

filosofering, rol van die Bybel in geloof en filosofie, verhouding tussen skriftuurlike filosofie, Dooyeweerd se siening van skriftuurlike filosofie, Klapwijk se siening van skriftuurlike filosofie, Vollenhoven se siening van wêreldbeskouing, Skrif en filosofie 